\title{
ELECTRORETINOGRAM DURING DEVELOPMENT OF HEREDITARY RETINAL DEGENERATION IN THE DOG*
}

BY

\author{
H. B. PARRY $\dagger$, KATHARINE TANSLEY, AND L. C. THOMSON
}

From the Animal Health Trust, Kennett, Newmarket, Suffolk, and the Institute of Ophthalmology, University of London

DURING an investigation of the electroretinogram of the dog (Parry, Tansley, and Thomson, 1953), some observations were made on Red Irish Setters suffering from hereditary degeneration of the retina. This form of retinal degeneration is inherited as a Mendelian recessive character and is characterized by degeneration of the rod nuclei at a very early age (Parry, 1953).

The degeneration results in night-blindness and loss of the electroretinogram in young animals. Later the dogs become totally blind.

In normal puppies the eyes open about 10-15 days after birth but no electroretinogram can be recorded until about 21 days when it is normal in general appearance but with a very small $b$-wave. From this age on the $b$-wave increases until it reaches its full size between 40 and 50 days (Fig. 1, overleaf).

This finding is in accordance with the results on mice reported by Keeler, Sutcliffe and Chaffee (1928), on rabbits by Demirchoglian and Mirzoian (1953), on man by Zetterström (1951), and on frogs by Müller-Limmroth and Andrée (1954). In none of these species can an electroretinogram be recorded from very young eyes.

We were interested to discover whether an electroretinogram can ever be obtained from a puppy suffering from this type of hereditary retinal degeneration, and if so, how its appearance and subsequent disappearance is related to the progress of the disease as determined by histological examination.

For this purpose we investigated a litter, both parents of which were known from previous matings and other criteria (Parry, 1951) to be affected so that all the offspring were homozygous for the retinal condition. There were six puppies in this litter born 60 days after coitus, of which five were first tested 22 days after birth. None produced an undeniable electroretinogram although two (DO 199 and DO 198) may have had a tiny $b$-wave (Fig. 2). One of the five died and was not examined histologically while another (DO 201) was killed and sections made of its retina. These showed some degeneration among the rod nuclei but no recognizable differentiation of their outer limbs. The remaining three dogs were tested again at 26 days, when DO 199 and DO 198 had definite electroretinograms and the third,

-Received for publication February 10, 1955. 


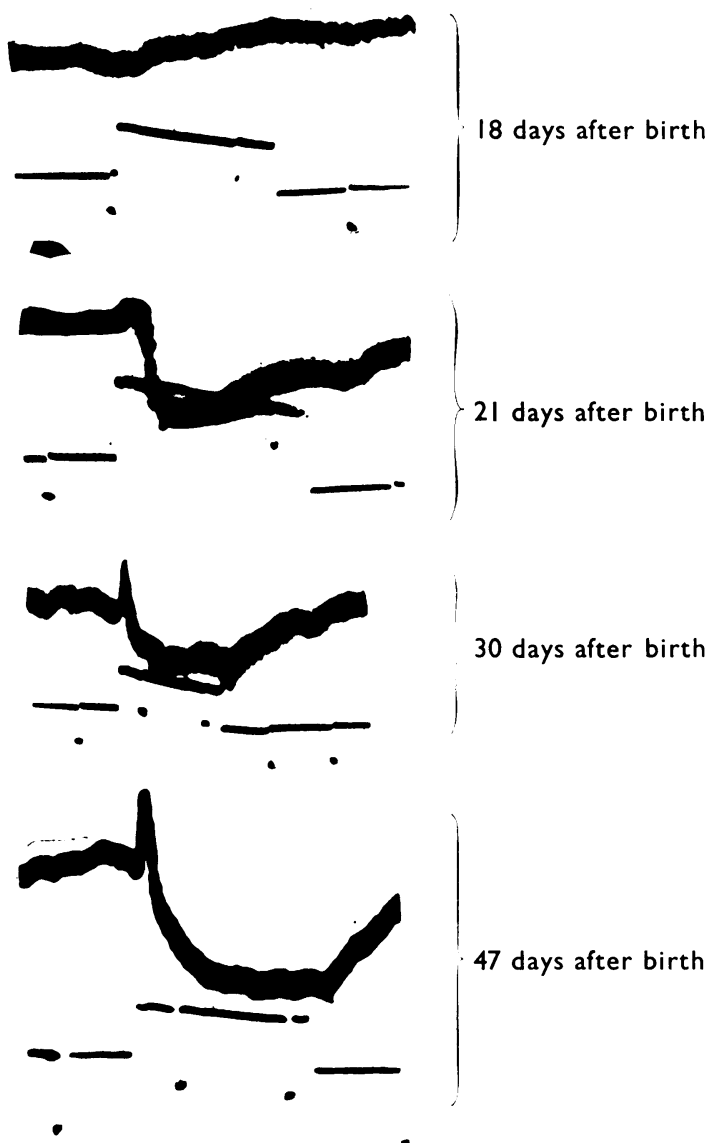

FIG. 1.-Development of electroretinogram in normal puppies. Upper trace, electroretinogram. Dots in lower trace $0.5 \mathrm{sec}$. Line displacement; upwards during presence of light stimulus.

DO 123 none. DO 199 was killed on this day and was found to have very heavy degeneration of the rod nuclei but also to show differential staining of the outer limbs. The two remaining dogs were tested for the third time at 32 days of age when DO 198 may have produced a very small $b$-wave; DO 123 certainly did not. The latter was killed on this day and found to have a marked outer nuclear degeneration and no recognizable outer limbs. The last dog was tested again at 36 and 48 days after birth. At 36 days the electroretinogram was still doubtful and at 48 days it was definitely absent. This dog was killed on the 48th day and found to have very few rods left at all. These findings are summarized in Fig. 2 and in the Table.

The Table shows that the ability to produce an electroretinogram is apparently much more closely connected with the presence of differentiated rod outer limbs than with the actual number of degenerating visual cell nuclei as judged by a histological count. In the dog the destruction of the 


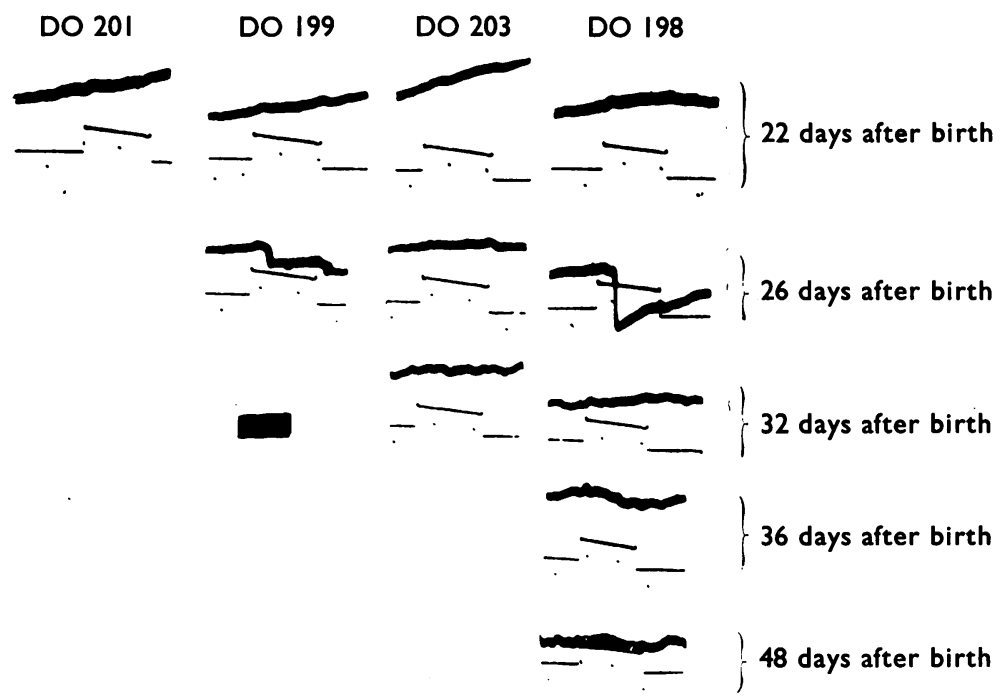

Fig. 2.-Development and disappearance of electroretinogram in a litter of diseased puppies.

Dots in lower trace $0.5 \mathrm{sec}$. Upper trace, electroretinogram. Line displacement; upwards during presence of light stimulus. Calibration $100 \mu \mathrm{V}$.

visual cells is spread over more than a month. A few degenerate cells have been seen in a puppy from a totally affected litter as early as 18 days after birth but degeneration reaches a peak at about 30 days after which the counts fall off as the number of rod nuclei decreases. Degenerate rod nuclei are found, but in steadily decreasing numbers, until there are no rods left in the retina.

TABLE

\begin{tabular}{|c|c|c|c|c|c|}
\hline \multicolumn{2}{|c|}{ Dog } & \multicolumn{2}{|c|}{ Outer Nuclear Layer of Retina } & $\begin{array}{c}\text { Outer } \\
\text { Limbs } \\
\text { of Rods }\end{array}$ & $\begin{array}{l}\text { Electro- } \\
\text { retino- } \\
\text { gram }\end{array}$ \\
\hline No. & $\begin{array}{l}\text { Post-natal } \\
\text { Age when } \\
\text { Examined }\end{array}$ & $\begin{array}{l}\text { No. of Degenerate } \\
\text { Nuclei counted in } \\
8 \mu \text { thick Section of } \\
\text { Whole Retina (mid- } \\
\text { dorsoventral plane) }\end{array}$ & $\begin{array}{l}\text { Thickness of Outer } \\
\text { Nuclear Layer in } \\
\text { Cells (normal value } \\
\text { in brackets) }\end{array}$ & $\begin{array}{l}\text { Pre } \\
\text { Abs }\end{array}$ & \pm \\
\hline $\begin{array}{l}\text { DO } 201 \\
\text { DO } 199 \\
\text { DO } 203 \\
\text { DO } 198\end{array}$ & $\begin{array}{l}22 \text { days } \\
26 \text { days } \\
32 \text { days } \\
48 \text { days }\end{array}$ & $\begin{array}{r}201 \\
1,789 \\
444 \\
244\end{array}$ & $\begin{array}{cc}10-12 & (14-16) \\
8-11 & (13-15) \\
5-6 & (12-14) \\
4-5 & (11-12)\end{array}$ & $\begin{array}{l}- \\
\pm \\
-\end{array}$ & $\underline{ \pm}$ \\
\hline
\end{tabular}

These results indicate, we think, that in this disease the rod develops a short but histologically differentiated outer limb and becomes capable of functioning as a photoreceptor before it begins to degenerate. In addition, the rods do not all become functional at the same time. If these assumptions 
are correct the presence or absence of an electroretinogram will depend on the balance between the number of rods which have become fully differentiated and functional and the number which have already died at the time of testing. Thus, in DO 201 only a few rods had developed far enough to show outer limbs or to have begun degeneration (in examining the sections one cannot be sure of the presence of differentiated outer limbs unless there are a fair number present). In DO 199 most of the rods had differentiated and, although a large number had subsequently died, enough were left to enable the retina to produce a measurable response to light. But in DO 203 and 198 too few remained capable of acting as photoreceptors. Such an interpretation of the results fits in with the histological findings of Bourne, Campbell, and Tansley (1938) in rats, Tansley (1951) in mice, and the original suggestion made by Treacher Collins (1919) as to the aetiology of retinitis pigmentosa in man. It is also strengthened by the observations of Keeler, Sutcliffe, and Chaffee (1928) and Demirchoglian and Mirzoian (1953) on mice and rabbits respectively, that an electroretinogram cannot be obtained from an eye until the rod outer limbs and visual purple have appeared.

An alternative possible explanation of the results described here might be that not all the rods degenerate at the same developmental stage, some being able to survive for a limited period after they have become functional.

\section{REFERENCES}

Bourne, M. C., Campbell, D. A., and TANSLey, K. (1938). British Journal of Ophthalmology, 22, 613.

ColLINS, E. TREACHER (1919). Trans. ophthal. Soc. U.K., 39, 165.

Demirchoglian, G. G., and Mirzoian, V. S. (1953). C.R. Acad. Sci. U.R.S.S., 90, 371.

Kerler, C. E., Sutcliffe, E., and Chaffee, E. L. (1928). Proc. nat. Acad. Sci. (Wash.), 14, 811.

Müller-Limmroth, H. W., and ANDrke, G. (1954). Z. Biol., 107, 25.

PARRY, H. B. (1951). Vet. Rec., 63, 323. (1953). British Journal of Ophthalmology, 37, 487.

, TANSLEY, K., and THOMSON, L. C. (1953). J. Physiol. (Lond.), 120, 28.

TANSLEY, K. (1951). British Journal of Ophthalmology, 35, 573.

ZETTERSTRöM, B. (1951). Acta ophthal. (Kbh.), 29, 295. 